\title{
An Unusual Cause of Chronic Scrotal Pain Coexisting with Hydrocele: Isolated Tuberculous Epididymitis
}

\author{
Kronik Skrotal Ağrı ve Hidroselin Sıradışı Nedeni: Izole Tüberküloz Epididimit
}

\author{
(1) Ibrahim Kartal1', (1) Fatih Sandıkçı1, (1) Ünsal Han², (1) Azmi Levent Sağnak1, (1) Hamit Ersoy¹ \\ 1 University of Health Sciences, Dışkapı Yıldırım Beyazıt Training and Research Hospital, Department of Urology, Ankara, Turkiye \\ 2 University of Health Sciences, Dışkapı Yıldırım Beyazıt Training and Research Hospital, Department of Pathology, Ankara, Turkiye
}

\begin{abstract}
Isolated tuberculous epididymitis (ITE) is a rare condition affecting only the epididymis without clinical evidence of renal involvement. One of the causes of chronic scrotal pain can be ITE, which is usually only diagnosed in the presence of strong clinical suspicion, as it was in this case. The patient who had chronic scrotal pain and hydrocele and who did not respond to medical treatment for the diagnosis of epididymitis underwent scrotal exploration. The pathology material demonstrated necrotizing and non-necrotizing granulomas in the epididymis and around the small vessels. The Mantoux test performed for differential diagnosis produced a positive result. The polymerase chain reaction done on the pathology material also produced results compatible with mycobacterium tuberculosis. The patient, who did not have postoperative systemic complaints, had his scrotal pain and swelling resolved with the completion of a 6-month anti-tuberculosis medical treatment. In ITE, which is rarely encountered, patients usually present with a painless scrotal mass. It must be taken into account that ITE may unusually cause scrotal pain, and even though not emphasized thoroughly until now, it may be accompanied by hydrocele as in our patient.
\end{abstract}

Keywords: Chronic scrotal pain, Hydrocele, Isolated tuberculous epididymitis

$\ddot{0 z z}$

İzole tüberküloz epididimit (iTE); böbrekte ve prostatta herhangi bir klinik kanıt olmadan sadece epididimit tutan genitoüriner tüberkülozun oldukça nadir görülen bir durumudur. Giderek sıklığı artan kronik skrotal ağrının çeşitli tespit edilebilir nedenleri olmasının yanında, olgumuzda da olduğu gibi ancak yüksek klinik şüphe ile tanıya gidilebilen ve tanısı oldukça zor olan ITE de bir neden olabilir.

Yaklaşık 1 yılı aşkın süredir kronik skrotal ağrısı ve hidroseli mevcut olan ve epididimit tanısıyla çeşitli medikal tedaviler uygulanıp, cevap alamayan hastaya skrotal eksplorasyon uygulandı. Patoloji materyalinde epididimde ve küçük damarlar etrafında nekrotizan ve non-nekrotizan granülomlar görülmesi nedeniyle ayırıcı tanı amaçlı yapılan tetkiklerde Mantoux testi pozitif bulundu. Mycobacterium tuberculosis enfeksiyonu; patoloji materyalinde yapılan polimeraz zincir reaksiyonunda tespit edildi. Preoperatif sistemik şikayetleri olmayan hastanın, cerrahi ve sonrasında 6 ay antitüberkülöz ilaçlarla ağrısı geçmiş ve skrotal şişliği tamamen ortadan kalkmış olarak tedavisi tamamlandı.

Çok nadir görülen ve ancak yüksek klinik şüpheyle tanıya ulaşılabilen ITTE, genellikle ağrısız skrotal kitle ile başvuran, özellikle endemik bölgelerde yaşayan ve risk faktörleri olan, bazen sıra dışı olarak, bizim olgumuzda da olduğu gibi kronik skrotal ağrı olgularında da görülebileceği unutulmamalı ve ayırıcı tanıda akla gelmelidir.

Anahtar Kelimeler: Kronik skrotal ağrı, Hidrosel, İzole tüberkülöz epididimit

\section{Introduction}

While in the genitourinary system, which is frequently affected by extrapulmonary tuberculosis (TB), the most frequently affected organs are the kidneys followed by the prostate, isolated tuberculous epididymitis (ITE) presents as a rare condition with difficult diagnosis affecting only the epididymis without clinical or laboratory evidence of renal involvement (1).

Chronic scrotal pain is defined as a constant or intermittent pain in the scrotal area that lasts for at least 3 months, interferes with the daily activities of the person, forces the person to

Correspondence: İbrahim Kartal MD, University of Health Sciences, Dışkapı Yıldırım Beyazıt Training and Research Hospital, Department of Urology, Ankara, Turkiye Phone: +90 5556298424 E-mail: igk84@hotmail.com ORCID-ID: orcid.org/0000-0002-2313-3522

Received: 31.07 .2018

Accepted: 23.10 .2018

Cite this article as: Kartal I, Sandıkçı F, Han Ü, Sağnak AL, Ersoy H. An Unusual Cause of Chronic Scrotal Pain Coexisting with Hydrocele: Isolated Tuberculous Epididymitis. J Urol Surg 2019;6(2):159-161.

๑Copyright 2019 by the Association of Urological Surgery / Journal of Urological Surgery published by Galenos Publishing House. 
demand medical treatment, and that can demonstrate unilateral or bilateral involvement (2). In this paper, in contrast to the conventional information existing in the literature, a patient who presented with chronic scrotal pain and hydrocele and was later diagnosed with ITE is presented.

\section{Case Presentation}

A 46-year-old male patient was referred to our clinic because of an increase in his pain despite having been treated with various antibiotics that primarily included ciprofloxacin and aminoglycosides and non-steroid anti-inflammatory medication for a diagnosis of epididymitis and accompanying hydrocele following the onset of swelling and pain in the right testis one year ago. The patient, manifesting no other features than pain and swelling in his history, presented normal systemic and rectal examinations, while in the physical examination a palpable mass was detected in his right testis that transilluminated, presented a swelling consistent with a hydrocele sac, and was located in an area conformable to epididymis. Visual analogue scale (VAS) pain score was determined as 8 , and pain impact questionnaire (PIQ-6, QualityMetrics Inc., Lincoln, RI, USA) pain score as 77. Scrotal Doppler ultrasonography (US) showed a heterogeneous hypoechoic lesion of $3.5 \times 2.7 \mathrm{~cm}$ in the epididymis and hydrocele of $8 \times 4 \mathrm{~cm}$ with heterogeneous right testis parenchyma and increased vascularity in the epididymis. The posteroanterior chest radiography taken preoperatively presented no lesions that could suggest TB and urinalysis and urine culture was sterile. No abnormalities were detected in the tests performed to evaluate preoperative systemic inflammation. In the surgery performed via right scrotal approach, no abnormalities were detected in the testis, however, the epididymis was stuck and hard. Caseous and necrotic discharge from the epididymis was present. The patient underwent hydrocelectomy and epididymectomy as the examination of the frozen biopsy from the epididymis did not appear consistent with malignity. The analysis of the pathological material revealed granulomas in the intraepididymal tissue that manifest necrosis in the center (Figure 1a) along with non-necrotising small granulomas and granulomatous vasculitis affecting the medium- and smalldiameter veins at multiple spots and causing necrosis on the blood vessel walls (Figure 1b)." Among the tests carried out for the purpose of differential diagnosis in the light of this result, only the Mantoux test turned out positive. The following polymerase chain reaction (PCR) test done with the pathological material was found to be positive for mycobacterium TB. The patient, who did not have TB in his medical history or family history and received anti-TB treatment for 6 months for the ITE diagnosis, was determined to have his scrotal pain and swelling resolved, with a VAS score of 2 and PIQ-6 score of 47.

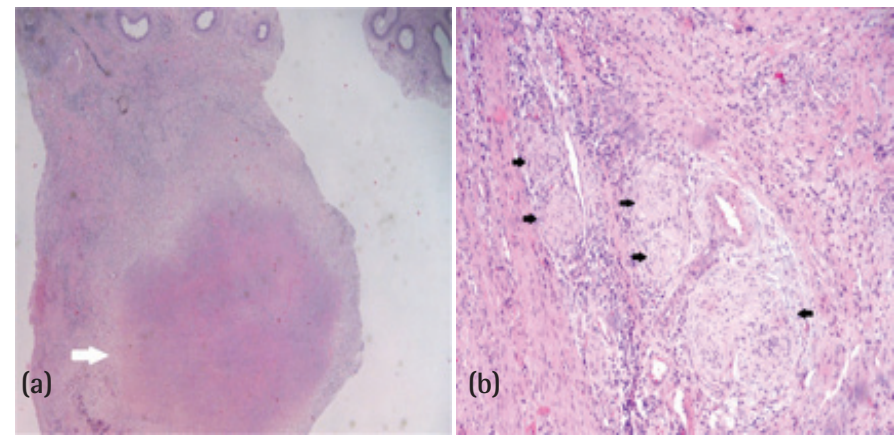

Figure 1. a) Microscopic view of the granuloma that nests necrosis in its center (white arrow) with localization neighboring the epididymal tissue (hematoxylin and eosin stain, x20); b) Microscopic view of the granuloma structures (black arrows) affecting veins of medium and small diameter (hematoxylin and eosin stain, $x 100$ )

Written informed consent was taken from the patient before the procedure.

\section{Discussion}

Scrotal TB infection makes up 7\% of all cases of TB, which is quite common across the world (3). While mycobacterium TB can reach the epididymis retrogradely through the prostate and seminal vesicles, its spread via lymphatic or hematogenous routes is also possible (1).

In ITE, which is mostly encountered in young adults, patients usually present due to scrotal mass without pain or with mild pain (4). It has been reported in a study that the primary complaint in patients diagnosed with ITE was pain in $40 \%$ of the cases (1). Although Drudi et al. (3) have reported that hydrocele could be seen in TB epididymitis, ITE-hydrocele coexistence has been highlighted in only a few case reports (5).

High-resolution US is the most appropriate method for the imaging of the scrotum. In order to diagnose ITE, suspicion is a prerequisite. Definitive diagnosis is made by fine needle aspiration (FNA) biopsy or pathological examinations following surgical resection of the epididymis (4). One must be selective and careful for the FNA biopsy procedure, taking malignancies into consideration. While it is quite difficult to diagnose tuberculous epididymitis, Liu HY et al. (4) have reported that preoperative scrotal magnetic resonance imaging and urine PCR could be useful in non-invasive diagnosis, particularly in the case of patients with a history of pulmonary TB.

TB epididymitis can be treated with anti-TB medication. Various treatment regimens exist. Surgery is recommended for patients not responding to medical treatment within 2 months or demonstrating intrascrotal abscess (6). A minimum of a 10-year follow-up period is suggested for treated patients. 
ITE, which is rarely seen and usually being detected in patients presenting with painless scrotal mass, must be considered in differential diagnosis especially in the presence of risk factors such as TB history, immunosuppressive therapy, history of travel to endemic regions, and long-lasting steroid use, and aside from the literature, in the presence of scrotal pain and hydrocele as encountered in our patient. In order to reach the diagnosis, clinical suspicion and differentiation from the more frequently encountered malignancies and inflammatory conditions such as epididymo-orchitis are essential. Patients of ITE, which is a condition that is challenging to diagnose early and accurately, can be cured with anti-TB treatment. Surgery is recommended for patients who do not respond to medical treatment, have abscess, and fail to receive a definitive diagnosis despite demonstrating serious clinical indications.

\section{Ethics}

Informed Consent: Written informed consent was taken from the patient before the procedure.

Peer-review: Externally peer-reviewed.

\section{Authorship Contributions}

Surgical and Medical Practices: I.G.K., F.S., A.L.S., H.E., Concept: I.G.K., A.L.S., Design: I.G.K., A.L.S., Data Collection or
Processing: I.G.K., F.S., Ü.H., Analysis or Interpretation: I.G.K., A.L.S., Literature Search: I.G.K., F.S., A.L.S., Writing: i.G.K., A.L.S., H.E.

Conflicts of Interest: No conflict of interest was declared by the authors.

Financial Disclosure: The authors declared that this study received no financial support.

\section{References}

1. Viswaroop BS, Kekre N, Gopalakrishnan G. Isolated tuberculous epididymitis: a review of forty cases. J Postgrad Med 2005;51:109-111.

2. Davis BE, Noble MJ, Weigel JW, Foret JD, Mebust WK. Analysis and management of chronic testicular pain. J Urol 1990;143:936-939.

3. Drudi FM, Laghi A, lannicelli E, Di Nardo R, Occhiato R, Poggi R, Marchese F. Tubercular epididymitis and orchitis: US patterns. Eur Radiol 1997;7:10761078.

4. Liu HY, Fu YT, Wu CJ, Sun GH. Tuberculous epididymitis: a case report and literature review. Asian J Androl 2005;7:329-332.

5. Manchanda S, Sharma BB, Kumar S. Tuberculous epididymo-orchitis: MRI appearance. Urol J 2012;9:351.

6. Gow JG, Barbosa S. Genitourinary tuberculosis. A study of 1117 cases over a period of 34 years. Br J Urol 1984;56:449-455. 